\title{
Dioctophyme renale: prevalence and risk factors of parasitism in dogs of Sáo Cristóváo district, Três Barras county, Santa Catarina State, Brazil
}

Dioctophyme renale: prevalência e fatores de risco de parasitismo em cães no distrito de São Cristóvão, Três Barras, Santa Catarina, Brasil

Daniela Pedrassani ${ }^{1 *}$; Adjair Antonio do Nascimento²; Marcos Rogério André3; Rosangela Zacarias Machado ${ }^{3}$

${ }^{1}$ Departamento de Medicina Veterinária, Universidade do Contestado - UnC, Canoinhas, SC, Brasil

${ }^{2}$ Departamento de Medicina Veterinária Preventiva e Reprodução Animal, Universidade Estadual Paulista - UNESP, Jaboticabal, SP, Brasil

${ }^{3}$ Departamento de Patologia Veterinária, Universidade Estadual Paulista - UNESP, Jaboticabal, SP, Brasil

Received October 6, 2016

Accepted January 17, 2017

\begin{abstract}
Dioctophyme renale is a nematode that can be found parasitizing the kidney, peritoneal cavity and, rarely, other organs of canids and mustelids. This disease has high occurrence in the municipality of Três Barras, state of Santa Catarina, thus making this an interesting area to study the epidemiological aspects of infection by D. renale in dogs. Among 197 dogs, $14.2 \%$ showed the parasite eggs in urine and $16.4 \%$ showed IgG antibodies anti- $D$. renale in serum samples according to the indirect ELISA method; among seropositive dogs, 15 (37.5\%) animals did not show any parasite eggs in their urine. Parasitism was more frequent in females, and there was no finding of interference from age on parasitism. Factors such as water potential and presence of paratenic hosts in the studied region were reported by the owners of dogs and may have contributed to the occurrence of parasitism.
\end{abstract}

Keywords: Kidney worm, Dioctophyme renale, epidemiology, ELISA.

\section{Resumo}

Dioctophyme renale é nematoda parasita de rins, cavidade peritoneal e, mais raramente, de outros órgãos de canídeos e mustelídeos. Esta parasitose tem ocorrência elevada no Município de Três Barras - SC, tornando essa área interessante para o estudo de aspectos epidemiológicos da infecção por D. renale em cães. De 197 cães examinados, 14,2\% apresentaram ovos do parasita na urina e $16,4 \%$ apresentaram anticorpos IgG anti- $D$. renale no soro pelo método de ELISA indireto e, entre estes, 15 (37,5\%) não apresentavam ovos do parasita sendo eliminados pela urina. O parasitismo foi mais frequente nas fêmeas, e não houve constatação de interferência da idade no parasitismo. Fatores como potencial hídrico e presença de hospedeiros paratênicos na região estudada foram relatados pelos tutores dos cães e podem contribuir para a ocorrência do parasitismo.

Palavras-chave: Verme renal, Dioctophyme renale, epidemiologia, ELISA.

\footnotetext{
*Corresponding author: Daniela Pedrassani. Departamento de Medicina Veterinária, Universidade do Contestado - UnC, Rua Roberto Ehlke, 86, CEP 89460-000, Canoinhas, SC, Brasil. e-mail: daniela@unc.br
} 


\section{Introduction}

Dioctophyme renale Goeze, 1782, is a nematode with worldwide distribution that can be found parasitizing the kidneys, peritoneal cavity and, more rarely, other organs of canids and mustelids (MEASURES, 2001). Its life cycle involves an intermediate host and can involve the presence of paratenic hosts such as fish and frogs, taking several months to complete (MEASURES, 2001; PEDRASSANI et al., 2009b). In dogs, the infection usually involves the right kidney. After destruction of the renal parenchyma, what remains is the mature nematode, encased in the fibrous capsule of the organ. Parasitized dogs can eliminate eggs in their urine, and these can be detected through examining the urinary sediment. $D$. renale eggs are oval, with clear yellow-brown coloration and their size variation is $62-75 \mu \mathrm{m}$ by $36-53 \mu \mathrm{m}$ (COSTA et al., 2004; PEDRASSANI et al., 2009a).

Dioctophyme renale has been reported from several countries including USA, Canada and Brazil (MEASURES, 2001; PEREIRA et al., 2006). It may have been Holarctic in origin, thereafter spreading to other parts of the world through translocation of infected hosts (especially dogs) or through susceptible animals' feeding on infected fish in enzootic areas (MEASURES, 2001). Despite wide distribution, its prevalence differs according to the region, ranging from $0.49 \%$ to $3.57 \%$ in different Brazilian states (KOMMERS et al., 1999; LEITE et al., 2005; PEREIRA et al., 2006) and little is known about the factors that encourage parasitism in dogs and other animal species. In the São Cristóvão district, in the municipality of Três Barras, Santa Catarina, southern Brazil, high prevalence of $D$. renale infection has been found in dogs. Between 2000 and 2003, the prevalence was 30\% in necropsied dogs (PEDRASSANI \& CAMARGO, 2004).

Because of this high frequency found in necropsies, the aim of the present study was to ascertain the prevalence among parasitized dogs by means of urinalysis and according to the presence of IgG antibodies against $D$. renale. Additionally, it was assessed whether parasitized dogs act as definitive hosts that enable continuation of the evolutionary cycle through elimination of fertile eggs of the parasite in urine and which predisposing factors contributing to parasitism in this region.

\section{Methodology}

Study area of study: The São Cristóvão district (longitude $50^{\circ} 22^{\prime} 53^{\prime}$ W; latitude $26^{\circ} 8^{\prime} 42^{\prime \prime} \mathrm{S}$ ) belongs to the municipality of Três Barras, state of Santa Catarina, Brazil and its population accounts for $46.13 \%$ of the entire population of the municipality (IBGE, 2007). Although this district forms part of the urban area of the municipality, it exhibits features that are transitional to the rural area and also has the particular characteristic of being the home of the less favored population of the municipality (LIMA, 2007). It is considered to have unfavorable socioeconomic conditions, without piped sewage disposal and without asphalt paving on most of the streets (BRASIL, 2014). The original vegetation of the region is classified as mixed ombrophilous forest, in which features of the original floristic composition still remain. However, the environmental situation in relation to water and riverbank vegetation is insecure (CUBAS, 2011).

Dogpopulation: This was a cross-sectional survey in which 197 apparently healthy mixed-breed dogs of different ages and sexes, living in homes in the São Cristóvão district, were taken to the Veterinary Hospital of the University of Contestado for blood and urine to be obtained and to perform pelvic ultrasound. These procedures were performed between March 2007 and February 2008, with consent from each animal's keeper.

In order to obtain a stratified random sampling, the district was divided into four regions and random samples were obtained from each of them, through randomly drawing the streets and homes to visit. All dogs in the same home were included in the sample.

Because no canine census exists in this region, the total population of dogs to be searched was estimated based on the ratio between the canine and human populations, as recommended by the World Health Organization and the Pasteur Institute (REICHMANN et al., 1999; WHO, 1990). Thus, through visits to 100 households in the district, a ratio of 1:5 was used. On this basis, the human population of the district (IBGE, 2007) was used to estimate the dog population to be sampled. This calculation was done using the Epi Info 3.4 .3 software with a sampling error of $6 \%$ and $95 \%$ confidence interval.

All procedures used in the present study was approved by the Research Ethics Committee of the University of Contestado (no. 67/2006).

Sedimentation method for detecting eggs in urine: Urine samples were obtained by means of bladder catheterization or cystocentesis and were centrifuged at $400 \mathrm{~g}$ for $5 \mathrm{~min}$. The sediment thus obtained was examined to search for eggs, under an optical microscope at a magnification of 40x (SLOSS et al., 1999). The sedimentation method was taken to be the gold standard for diagnosing parasitism caused by $D$. renale.

Evaluation of eggs: The sediment containing parasite eggs that resulted from centrifugation of urine samples from positive animals was suspended using $3 \mathrm{~mL}$ of water, in Petri dishes. These samples were kept for 90 days or until formation of larvae, in a BOD incubator $\left(\mathrm{T}=26 \pm 0.5^{\circ} \mathrm{C}\right.$; humidity $\left.=80 \%\right)$. Eggs were considered to be fertile if larvae developed inside them and infertile if no larvae developed under the same conditions.

Ultrasonography: Ultrasonography was performed in all sampled dogs, using the Ultrasound Pie Medical-100 device, with a linear transducer at a frequency of $5.0 \mathrm{MHz}$, in order to show changes in abdominal organs (especially the kidneys, liver and abdominal cavity) and to show parasite structures.

Serum samples: Blood samples were collected from the cephalic or jugular vein and were placed in tubes without anticoagulant in order to obtain serum, which was stored in microtubes and frozen at $-20{ }^{\circ} \mathrm{C}$ until use.

Indirect ELISA test: The protocol used for producing antigen and detecting $\operatorname{IgG}$ antibodies against $D$. renale was performed as previously reported by Pedrassani et al. (2015). The cutoff point was determined as the mean absorbance of negative control serum samples with the addition of twice the standard deviation. Serum samples from naturally parasitized dogs were used as positive controls $(n=5)$. Serum samples from dogs in Três Barras that showed negative results both from urinalysis and from 
abdominal ultrasound, and one sample obtained from a newborn dog in Jaboticabal, state of São Paulo (longitude $48^{\circ} 17^{\prime} 31^{\prime \prime} \mathrm{W}$; latitude $21^{\circ} 14^{\prime} 41^{\prime \prime} \mathrm{S}$ ), which is an area that is not endemic for dioctophymiasis, were used as negative controls $(n=27)$.

Statistical analysis: The prevalence obtained through the indirect ELISA test was established in accordance with the sensitivity and specificity of the standardized technique (THRUSFIELD, 2004). A questionnaire was applied to the dogs' owners, to assess the prevalence of risk factors for parasitism caused by $D$. renale in the region, among parasitized and non-parasitized animals. The prevalence ratio (PR) was calculated with a $95 \%$ confidence interval and its significance was determined by means of the $\chi^{2}$ test or Fisher's exact test with $\mathrm{p} \leq 0.05$, in the Epi Info software (THRUSFIELD, 2004). The risk factors analyzed were age, sex, type of feed supplied to the animal, access to water sources and contact with paratenic and intermediate hosts.

\section{Results and Discussion}

In the studied district, 28 dogs (14.2\%) presented patent kidney parasitosis, since they were showed parasite eggs in their urinary sediment. It is important to state the possibility that more dogs were parasitized but under non-patent infection, presence of young nematodes, and/or location of parasites outside the kidney or parasitism by only males parasites. In the same district, between 2000 and 2003, 40 dogs were necropsied and 30\% was found to be parasitized by this renal helminth (PEDRASSANI \& CAMARGO, 2004). In the present study, with extended sampling ( $\mathrm{n}=197)$ from different parts of the district, the percentage of parasitism detected through urinalysis was $14.2 \%$. Similar findings were reported by Measures (2001), who stated that although $D$. renale was widely distributed, it only occurred in enzootic areas in which the prevalence among the hosts varies from year to year.

In Argentina, the prevalence data for different years in the same location have also been divergent. An investigation on $D$. renale eggs in urinary sediment from street dogs in 2002 found that $4.16 \%(1 / 24)$ of the cases were positive, whereas all the samples were negative in 1985 (0/76) (CHAMORRO \& MORIENA, 2003). Burgos et al. (2014), in a wild riverside area of La Plata River, Buenos Aires, found 42,1\% of male dogs positive for $D$. renale, according to urine tests. In Uruguaiana, state of Rio Grande do Sul, Brazil, among 475 dogs, 1.68\% were positive for parasite eggs in their urine: $2 \%$ (6/300) among dogs living in homes and $1.14 \%$ among the 175 stray dogs necropsied (COLPO et al., 2007).

In studies by Chamorro \& Moriena (2003) and Colpo et al. (2007), the prevalences of parasitized animals were well below those observed in São Cristóvão district. This suggests that the local conditions of the present study were more favorable for maintenance and dissemination of this nematode, although the prevalence observed here was lower than what was observed by Pedrozo et al. (2013) in the city of Caazapá, Paraguay, where 20\% of the dogs were positive according to urine tests.

Females were significantly more affected by $D$. renale than males, with percentage positivity of $28.2 \%$ and $10.7 \%$ respectively $\left(\chi^{2}=7.81, p=0.005\right)$. Taking into account only the positive animals, the prevalence of positive findings was 2.62 times greater among female dogs. The possible risk factors associated with infection are found outdoors, in situations of backyards adjacent to rivers or stream, animals fed with fish offal and the possibility of contact with frogs. Another factor that contributes towards higher rates of parasitism among females may be immunosuppression caused by frequent pregnancies, since birth control practices are rarely undertaken among dogs at this locality (Table 1).

$D$. renale parasitizes dogs of different ages and both sexes. Coppo \& Brem (1983) observed a difference in parasitism between the sexes, with higher frequency in females, but they only had three subjects (two females and one male). In other studies, there was higher detection of the parasite in males: among eight dogs that were parasitized, six were males and two were females (COLPO et al., 2007); besides, among 28 dogs parasitized in the West Frontier region of Rio Grande do Sul State, Brazil, 11 were females and 17 were males (SILVEIRA et al., 2015).

In relation to Mustela vison, Mace \& Anderson (1975) observed that males were significantly more frequently parasitized than females. However, although Mech \& Tracy (2001) also observed greater parasitism among males, there was no significant difference in comparison with females. One hypothesis for this gender-based dissimilarity, suggested by those authors, is that males may have larger territories than females, which could mean greater exposure to infected prey. Another possibility is that males may consume more intermediate and paratenic hosts.

The positivity rate among the dogs was $16.1 \%$ for those aged up to 1.5 years; $11.8 \%$ for those aged 1.6 to five years; and $19.1 \%$ for those aged over five years. There was no statistically significant difference in positivity for $D$. renale $\left(\chi^{2}=1.63, p=0.445\right)$, neither between the ages of up to five years and over 5 years (Table 1 ). The data concerning the ages of the parasitized dogs coincided with those obtained by Mech \& Tracy (2001). Burgos et al. (2014) and Silveira et al. (2015) detected this renal parasitosis mainly in dogs over 2 years of age.

The pattern of natural and experimental infections suggested that the hosts became infected only once (Hallberg, 1953). Thus, prevalence that is similar at different ages can indicate that dogs are infected when they are very young or even puppies, and that they remain infected for long periods. On the other hand, Burgos et al. (2014) found a low prevalence of $D$. renale in male up to 1-year-old dogs, attributing this fact to the attention they received from owner, avoiding exposure to infectious forms.

Among the 28 parasitized dogs, the location of the parasites was determined by means of ultrasound, surgery or necropsy in 22 cases. The parasite was located in the right kidney in 18 of them; one was in the abdominal cavity and three were in both the right kidney and the abdominal cavity. In six dogs for which it was not possible to perform a sonogram, because of non-cooperation from the owner, parasite eggs were found to be eliminated in urine, thus suggesting parasitism of the kidney.

In five dogs that were subjected to nephrectomy or necropsy, parasites were removed and measured. Among these dogs, four had few parasites in the right renal location and one had a parasite in the cavity but also presented a lesion with rupture of the capsule in the right kidney, thus suggesting that the parasite had migrated from the kidney to the cavity. The animals presented between 
Table 1. Prevalence ratio for dioctophymosis compared between groups of dogs exposed and not exposed to risk factors for parasitism $(\mathrm{n}=197)$.

\begin{tabular}{|c|c|c|c|c|c|c|}
\hline \multirow{2}{*}{ Risk factor } & \multicolumn{2}{|c|}{$\begin{array}{l}\text { D. renale-positive } \\
\text { (Cases) }\end{array}$} & \multicolumn{2}{|c|}{ D. renale-negative (Controls) } & \multirow{2}{*}{ PR (95\% CI) } & \multirow[t]{2}{*}{$P$} \\
\hline & $\mathbf{N}$ & $\%$ & $\mathbf{n}$ & $\%$ & & \\
\hline \multicolumn{7}{|l|}{ Dog's sex } \\
\hline Male & 17 & 60.7 & 141 & 83 & $0.38(0.19-0.75)$ & 0.0052 \\
\hline Female & 11 & 39.3 & 28 & 17 & $2.62^{*}(1.34-5.14)$ & \\
\hline \multicolumn{7}{|l|}{ Dog's age } \\
\hline Up to 5 years & 19 & 67.8 & 131 & 77.5 & $0.66(0.32-1.36)$ & 0.2667 \\
\hline Over 5 years & 9 & 32.2 & 38 & 22.5 & $1.51(0.73-3.11)$ & \\
\hline \multicolumn{7}{|c|}{ Owner is fed with fish from the Canoinhas river } \\
\hline Yes & 17 & 60.7 & 59 & 35 & $2.46^{*}(1.22-4.97)$ & 0.0093 \\
\hline No & 11 & 39.3 & 110 & 65 & $0.41(0.20-0.82)$ & \\
\hline \multicolumn{7}{|c|}{ Owner feeds dog with raw fish or raw viscera of fish } \\
\hline Yes & 11 & 39.3 & 32 & 19 & $2.32^{*}(1.18-4.57)$ & 0.0157 \\
\hline No & 17 & 60.7 & 137 & 81 & $0.43(0.22-0.85)$ & \\
\hline \multicolumn{7}{|c|}{ Dog plays with, bites or eats frogs } \\
\hline Yes & 15 & 53.5 & 52 & 30.7 & $2.24^{*}(1.13-4.43)$ & 0.0183 \\
\hline No & 13 & 46.5 & 117 & 69.3 & $0.45(0.23-0.88)$ & \\
\hline \multicolumn{7}{|c|}{ Dog overturns trash can and has access to food remains } \\
\hline Yes & 15 & 53.5 & 71 & 42 & $1.49(0.75-2.96)$ & 0.2533 \\
\hline No & 13 & 46.5 & 98 & 58 & $0.67(0.34-1.34)$ & \\
\hline \multicolumn{7}{|c|}{ Dog frequents the nearby Canoinhas river } \\
\hline Yes & 21 & 75 & 98 & 58 & $1.97(0.88-4.40)$ & 0.0882 \\
\hline No & 07 & 25 & 71 & 42 & $0.51(0.23-1.14)$ & \\
\hline \multicolumn{7}{|c|}{ Dog drinks water from the Canoinhas river } \\
\hline Yes & 18 & 64 & 54 & 32 & $3.13^{*}(1.53-6.40)$ & 0.0009 \\
\hline No & 10 & 36 & 115 & 68 & $0.32(0.16-0.66)$ & \\
\hline \multicolumn{7}{|c|}{ Dog drinks water from flow channels of the Canoinhas river } \\
\hline Yes & 20 & 71.4 & 70 & 41.4 & $2.97^{*}(1.38-6.42)$ & 0.0031 \\
\hline No & 08 & 28.6 & 99 & 58.6 & $0.34(0.16-0.73)$ & \\
\hline \multicolumn{7}{|c|}{ Owner already noted annelids in the Canoinhas river } \\
\hline Yes & 10 & 36 & 63 & 37.2 & $0.94(0.46-1.93)$ & 0.8739 \\
\hline No & 18 & 64 & 106 & 62.8 & $1.06(0.52-2.17)$ & \\
\hline
\end{tabular}

$\mathrm{PR}=$ prevalence ratio; $\mathrm{CI}=$ confidence interval; $P=$ p value from chi-square test. $*$ Significant with $5 \%$ probability.

one and four parasites. The levels of parasite aggregation tend to vary in inverse proportion to their pathogenicity (ANDERSON \& GORDON, 1982). This characteristic and possible lasting immunity may be factors that contribute towards the observation that most dogs with parasitism caused by $D$. renale have infections with small number of parasites.

In Cachoeira do Itapemirim, Espírito Santo State, in 2004, 56 dogs at an animal control center were necropsied. Of these, $3.57 \%$ presented D. renale in the right kidney, and in $50 \%$ of the cases there were helminths of both sexes in the same kidney (PEREIRA et al., 2006).

Mehlhorn (2001) considered that the location of this parasite in the peritoneal cavity in dogs might suggest that these animals are not the definitive natural hosts. However, in M. vison, which is considered to be a natural host of the parasite (MEASURES, 2001), infection also occurs in the peritoneal cavity. In study by Mech \& Tracy (2001), 54\% of trapped mink had cysts in the right kidney with parasites of both sexes, and in $14 \%$ of the cases, there were parasites only in the abdominal cavity.
Mink are considered to be definitive hosts of $D$. renale in nature, given that they show parasitism with large numbers of parasites of both sexes. These are generally located in the kidneys, which favors output of fertile eggs to the environment (MEASURES, 2001).

Kommers et al. (1999) suggested that dogs act as definitive hosts in abnormal and terminal situation because of the predominance of parasitism that does not allow the parasite's life cycle to be completed. However, several authors have reported cases of multiple parasitism in dogs (KANO et al., 2003; MONTEIRO et al., 2002; PEREIRA et al., 2006; RAPPETI et al., 2008).

Development of the eggs from urine samples from 17 (60.7\%) parasitized dogs resulted in first-stage larvae (L1), which indicates that a large percentage of the dogs were eliminating fertile eggs of the parasite into the environment of the region studied. The urine samples from six dogs (three males and three females) did not have any fertile eggs. In the cases of five other dogs (three females and two males), it was not possible to make any new urine collection, because the animal died or disappeared, or the owner did not give permission for new sampling procedures. Among the urine samples in which it was observed that fertile eggs were 


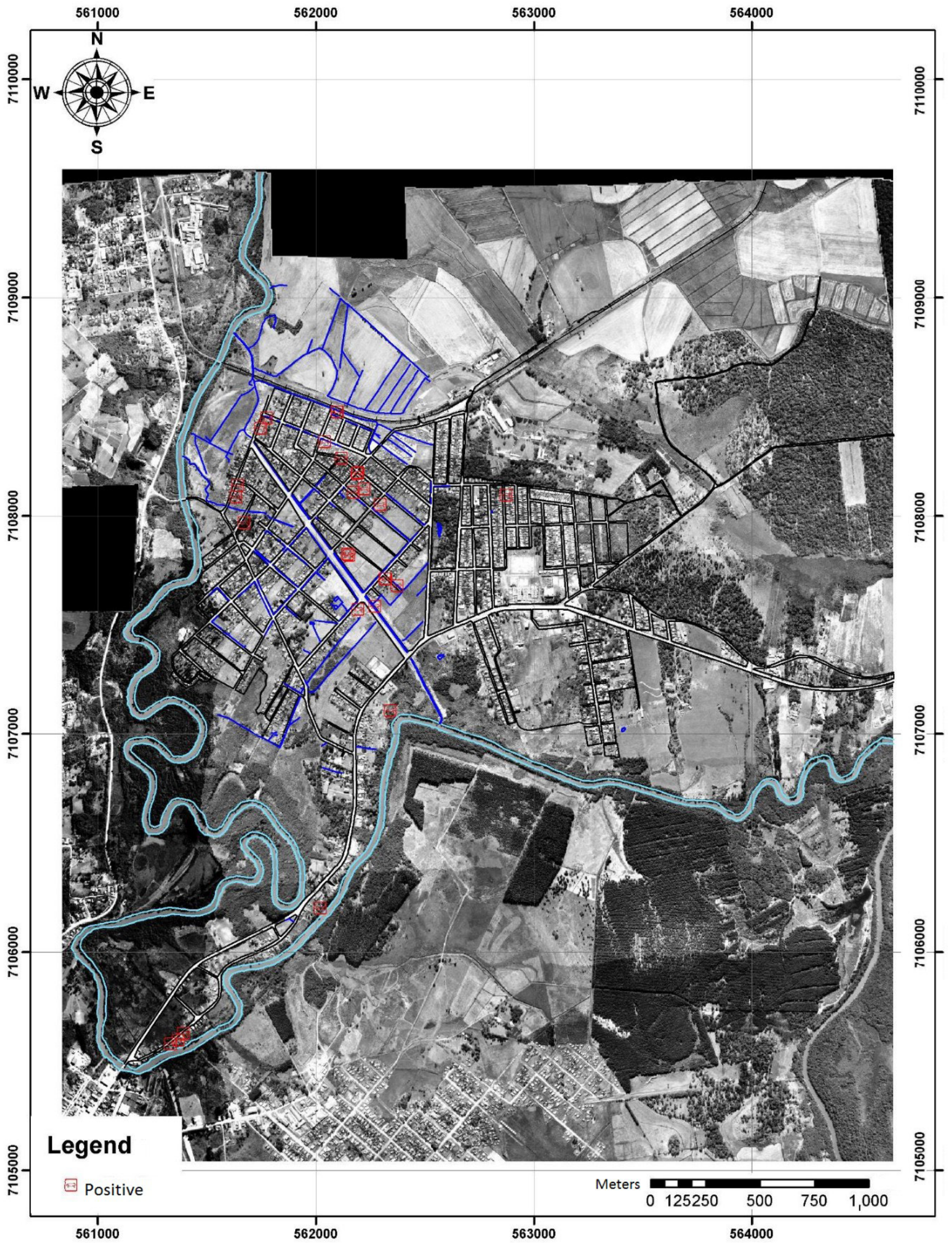

Figure 1. Places where the parasitized dogs in the São Cristóvão District, Três Barras, Santa Catarina, Brazil, were living. Note: red represents site with parasitized dogs; light blue represents the canoinhas river; and dark blue represents flow channels of the Canoinhas river. 
released, 12 of the dogs were males and five were females. Thus, although there was a higher percentage of parasitized females in the region studied, the parasites attained the best conditions for multiple parasitism, maturation and subsequent excretion of the helminth eggs through urine among the male dogs. Testosterone reduces host resistance to parasitic infections, thereby resulting in higher prevalence and intensity of these infections in males of most species of mammals (RIVERO et al., 2002).

Egg development is fundamental for continuing the biological cycle of $D$. renale and depends on the temperature. The optimal temperature required for egg embryogenesis is between 25 and $30^{\circ} \mathrm{C}$, under which conditions the first-stage larvae are observed within 30 days. However, at low temperatures, this may take up to seven months (FREITAS, 1980). Pedrassani et al. (2009b) found that $50 \%$ of the eggs were embryonated, 18 days after incubation at a temperature of $26^{\circ} \mathrm{C}$. Cell division was not observed in eggs maintained at temperatures of 6 to $10^{\circ} \mathrm{C}$, but there was continuity of evolution when the temperature reached at $14^{\circ} \mathrm{C}$ (MACE \& ANDERSON, 1975).

Although Measures (2001) considered that, in South America, $D$. renale transmission probably occurs throughout the year, the subtropical climate in the southern region of Brazil, and specifically in the district studied here, is unfavorable for evolution of this nematode at some times of the year, particularly in winter. In the region studied, in late autumn and winter, in the years 2006, 2007 and 2008 , the average temperature was below $10{ }^{\circ} \mathrm{C}$, a condition that is unfavorable for egg development. At other times of the year, the average temperatures would allow embryogenesis in eggs, but the length of these times might be prolonged in years with mild temperatures.

The spatial distribution of dioctophymiasis is caused by the interaction between biotic and abiotic environmental factors. Concentration of domestic animals (dogs) and wild animals (fish and frogs) in restricted areas facilitates increased environmental contamination by helminth eggs and worms in paratenic hosts, thereby favoring the infection. In the studied area, the environmental conditions are suitable for development and survival of pre-parasitic forms like rivers, flooding, and the presence of infected definitive (PEDRASSANI \& CAMARGO, 2004) and paratenic hosts (PEDRASSANI et al., 2009b).

The owners of the examined dogs were asked about matters, such as the type of food provided for the animal, access to water sources and contact with paratenic hosts, because there are no data on risk factors that can favored the occurrence canine dioctophymosis.

All the owners reported that they fed their animals with food leftovers, and $6 \%$ reported that they also occasionally gave them commercial feed. Regarding consumption of fish from the Canoinhas river by the owners, it was observed that among those who had this habit, their dogs showed prevalence of dioctophymosis that was 2.46 times greater than in those animals whose owners did not use this source of food. Furthermore, among the dogs that were fed with raw fish or raw fish viscera, the level of parasitism due to $D$. renale was 2.32 times greater than among the dogs that did not receive this type of food (Table 1). Costa et al. (2004) indicated that dogs with this helminth had poorly selected feed. Thus, it is believed that this issue contributed to the high prevalence observed in the present study, because the dogs lived in a poor district of the municipality of Três Barras, Santa Catarina State. The data presented are in accordance with Burgos et al. (2014) that have suggested that the high prevalence of $D$. renale in dogs is related to the consumption of potential paratenic hosts (frogs and fishes) and with the fact that the dog drinks water from ditches.

The dogs with the habit of playing with, biting and eating frogs showed a prevalence that was 2.24 times greater than among those without this behavior (Table 1). Given that the district studied is a deprived area, the dogs suffer from hunger, it is common to see that dogs on the streets retrieve frogs that had become roadkill and feed on their corpses. This association is strengthened by the fact that, in the São Cristóvão district, larvae of $D$. renale were found in the stomach of Chaunus ictericus, thus indicating that this species of frog acts as a paratenic host and also as an environmental indicator for the presence of this nematode in the region (PEDRASSANI et al., 2009b).

Mace \& Anderson (1975) analyzed the stomach content of M. vison and found fragments of frogs in $24 \%$, thus indicating that these paratenic hosts of $D$. renale are part of their diet.

Given that parasitism occurs more frequently among dogs that have unselective eating habits (KOMMERS et al., 1999; ZAKARIAN \& SHAFAII-TONKABONI, 1972), it can therefore be assumed that these animals became infected through directly ingesting the intermediate host (oligochaetes) or paratenic hosts such as fish (or their viscera) and frogs/toads.

Some authors describe the freshwater oligochaete annelid, Lumbriculus variegatus, as an intermediate host that may infect paratenic and definitive hosts (MACE \& ANDERSON, 1975; MEASURES, 2001). However, to the best of authors's knowledge, there is not report of finding of Dioctophyme larvae in intermediate hosts in South America so far. This annelid species was reported in Brazil only in 2011 or 2012 (MARCHESE et al., 2015). The activity of viewing aquatic annelids in the Canoinhas River among the owners did not result in a higher percentage of parasitized dogs. The explanation for this is that the intermediate host $L$. variegatus is 4 to $10 \mathrm{~cm}$ in length and lies under the sludge layer at the bottom of the river. This makes it difficult for people to view them.

Dogs' access to the Canoinhas River was investigated and there was a significantly higher prevalence of parasitism in the group of dogs that ingested water from the river (3.13 times more) or from its flow channels (2.97 times more) than among those without these habits. However, given that only the nearby river was surveyed, there was no significant difference in the prevalence of parasitism between the groups (Table 1).

In this district, which is delimited by the Canoinhas River, there was greater detection of animals with parasitism in its lower part, where most of the flow channels are located, and also in homes right next to the river (Figure 1).

The parasitized animals' access to aquatic environments explains its importance in relation to transmission of $D$. renale (KANO et al., 2003; PEREIRA et al., 2006; BURGOS et al., 2014). The dogs reported here inhabited the banks of a river located within the district. This river is important to the region, since leisure activities, water extraction and fishing activities are developed along its stream. In addition, in this region, there are many channels for dispersal of the waters of this river to prevent 
flooding (Figure 1). This is important not only in relation to parasitism among dogs, but also because infection by this parasite is zoonotic (URANO et al., 2001; IGNJATOVIC et al., 2003; TOKIWA et al., 2014). This may be affecting the population of the district and verification of this high prevalence in dogs indicates that there is a need for studies concerning the prevalence in humans, mainly because the population use the river to fishing for food (fish, frogs), drinking and recreation. According to Kano et al. (2003), animals infected by the parasite can be used as sentinels for the human population, since this population is exposed to the same predisposing factors as the animals.

Dogs with the habit of rummage in garbage did not show higher prevalence of parasitism than those without this habit.

The data suggest that in the district studied, there was an association between the factors predisposing towards disease and higher prevalence of parasitism in dogs exposed to these factors. Moreover, findings of larvae of $D$. renale in frogs in the São Cristóvão district made a contribution (PEDRASSANI et al., 2009b).

Immunological tests are not widely used in diagnosing helminth infections because these are generally easier to diagnose by examining the stools or urine for the presence of parasite eggs. However, there are some forms of helminthiasis such as heartworm and trichinellosis, in which the eggs are not eliminated and the serological diagnosis becomes almost essential. In these cases, the ELISA test is a useful diagnostic technique. In dioctophymosis, the animals are primarily diagnosed through necropsy or demonstration of eggs in the urine. However, eggs are detected in the urine of dogs with renal parasitism, but are not present in the urine of those with extrarenal parasitism or with parasites of only one sex or in immature forms. Therefore, the indirect ELISA test was used as an alternative for diagnosing parasitism in these dogs, through detection of specific antibodies in the serum.

Among the dogs that underwent urine examination and also the ELISA test, only three animals that were found to be positive in the urine sediment examination $(n=28)$ were not positive according to ELISA.

Among the serum samples tested by means of indirect ELISA, 40 were reactive to the antigen of $D$. renale and, among these dogs, 15 did not show any parasite eggs in their urine. This seroreactivity may have been due to the presence of animals with immature or male parasites or with parasites in extrarenal location, which were detected through the antigen produced in the esophagus of $D$. renale.

Investigation of $\operatorname{IgG}$ antibodies against $D$. renale, through the ELISA test, showed that the prevalence of canine dioctophymosis was $20.3 \%$. However, the prevalence of positive results from a diagnostic test on a population is not synonymous with the prevalence of the disease in this population. That would only be true if a test with $100 \%$ sensitivity and specificity were to be used (THRUSFIELD, 2004). According to the sensitivity and specificity levels of the standardized ELISA test $(S=92.3 \%$; $93.8 \%$ ) the prevalence was $16.4 \%$. This figure was quite close to the prevalence of $14.2 \%$ obtained through investigating parasite eggs in the urine. It indicates that there was a correlation of results between the routine method and the standardized ELISA test and also that this technique is applicable to epidemiological studies.

\section{Conclusion}

Given that canine dioctophymosis is a disease that is considered of low prevalence in dogs, the prevalence of the disease in the São Cristóvão district, in the state of Santa Catarina, can be taken to be high. This parasitism was shown to be statistically independent of the dog's age and it was also found to be more common among females.

The amount of water and the paratenic hosts in the region are factors that were present in this region and, when associated, might have contribute to the occurrence of parasitism.

Parasitized dogs contributed towards environmental contamination through infectious forms of $D$. renale eliminated by urine.

This epidemiological study in this endemic area for canine dioctophymosis demonstrates that a considerable percentage of the dogs presented evidence of $D$. renale infection through positive serological reactions, but without presenting clinical signs of the disease or elimination of the parasite eggs in the urine.

\section{References}

Anderson RM, Gordon DM. Processes influencing the distribution of parasite number within host population with special emphasis on parasite-induced host mortalities. Parasitology 1982; 85(2): 373-398. PMid:7145478. http://dx.doi.org/10.1017/S0031182000055347.

Brasil. Ministério das Cidades. Secretaria Nacional de Saneamento Ambiental. Série histórica [online]. Brasília; 2014 [cited 2016 July 20]. Available from: http://app.cidades.gov.br/serieHistorica/\#

Burgos L, Acosta RM, Fonrouge RD, Archelli SM, Gamboa MI, Linzitto OR, et al. Prevalence of a zoonotic parasite, Dioctophyma renale (GOEZE, 1782), among male canine in a wild riverside area of La Plata Reiver, province de Buenos Aires, Republic of Argentina. Rev Patol Trop 2014; 43(4): 420-426.

Chamorro V, Moriena RA. Diagnóstico e incidencia de la dioctophymosis en la Ciudad de Corrientes, Argentina [online]. Zaragoza: Portal Veterinaria; 2003 [cited 2008 July 20]. Available from: http://argos.portalveterinaria. com/noticia/1393/articulos-archivo/diagn\&oacutestico-e-incidencia-dela-dioctophymosis-en-la-ciudad-de-corrientes-argentina.html

Colpo CB, Silva AS, Monteiro SG, Stainki DR, Camargo DG, Colpo ETB. Ocorrência de Dioctophyma renale em cáes no Município de Uruguaiana - RS. Rev FZVA 2007; 14(2): 175-180.

Coppo JA, Brem JJ. Canine Dioctophymosis in the north east of Argentine. Rev Inst Med Trop Sao Paulo 1983; 25(5): 259-262. PMid:6231710.

Costa PRS, Argôlo Neto NM, Oliveira DMC, Vasconcellos RS, Menezes FM. Dioctofimose e leptospirose em um cão - relato de caso. Rev Clín Vet 2004; 9(51): 48-50.

Cubas R. Florística, estrutura e dinâmica em uma Floresta Ombrófila Mista no Norte do Estado de Santa Catarina [Dissertation]. Irati: Universidade Estadual do Centro-Oeste; 2011.

Freitas MG. Helmintologia veterinária. 4th ed. Belo Horizonte: Rabelo; 1980.

Hallberg CW. Dioctophyma renale (Goeze, 1782) a study of the migration routes to the kidneys of mammals and resultant pathology. Trans Am Microsc Soc 1953; 72(4): 351-363. http://dx.doi.org/10.2307/3223483. 
Ignjatovic I, Stojkovic I, Kutlesic C, Tasic S. Infestation of the human kidney with Dioctophyma renale. Urol Int 2003; 70(1): 70-73. PMid:12566820. http://dx.doi.org/10.1159/000067695.

Instituto Brasileiro de Geografia e Estatística - IBGE. População residente: Três Barras [online]. Rio de Janeiro: IBGE; 2007 [cited 2007 Mar 12]. Available from: http:/www.ibge.gov.br/home/estatistica/populacao/ contagem2007/default.shtm

Kano FS, Shimada MT, Suzuki SN, Osaki SC, Menarim BC, Ruthes FRV, et al. Ocorrência da dioctofimose em dois cães no município de Guarapuava - PR. Semina: Ciênc Agrár 2003; 24(1): 177-180.

Kommers GD, Ilha MRS, Barros CSL. Dioctofimose em cães: 16 casos. Cienc Rural 1999; 29(3): 517-522. http://dx.doi.org/10.1590/S010384781999000300023.

Leite LC, Círio SM, Diniz JMF, Luz E, Navarro-Silva MA, Silva AWC, et al. Anatomopathologic lesions found in Dioctophyma renale (Goeze, 1782) infections in domestic dogs (Canis familiaris, LINNAEUS, 1758). Arch Vet Sci 2005; 10(1): 95-101. http://dx.doi.org/10.5380/avs.v10i1.4091.

Lima SRS. Capital transnacional na indústria da madeira em Três Barras: as company tows e a produção do espaço urbano [Dissertation]. Curitiba: Universidade Federal do Paraná; 2007.

Mace TF, Anderson RC. Development of the giant kidney worm, Dioctophyma renale (Goeze, 1782) (Nematoda: Dioctophymatoidea). Can J Zool 1975; 53(11): 1552-1568. PMid:127653. http://dx.doi. org/10.1139/z75-190.

Marchese MR, Santos MR, Lima JCS, Pamplin PAZ. First record of introduced species Lumbriculus variegatus Müller, 1774 (Lumbriculidae, Clitellata) in Brazil. BioInvasions Rec 2015; 4(2): 81-85. http://dx.doi. org/10.3391/bir.2015.4.2.02.

Measures LN. Dioctophymatosis. In: Samuel WM, Pybus MJ, Kocan AA. Parasitic diseases of wild mammals. 2nd ed. Iowa: Iowa State University Press; 2001. p. 357-364.

Mech LD, Tracy SP. Prevalence of giant kidney worm (Dioctophyma renale) in wild mink (Mustela vison) in Minnesota. Am Midl Nat 2001; 145(1): 206-209. http://dx.doi.org/10.1674/0003-0031(2001)145[0206:PO GKWD]2.0.CO;2.

Mehlhorn H. Encyclopedic reference of parasitology: diseases, treatment, therapy. 2nd ed. Berlin: Springer; 2001.

Monteiro SG, Sallis ESV, Stainki DR. Infecção natural por trinta e quatro helmintos da espécie Dioctophyma renale (Goeze,1782) em um cáo. Rev FZVA 2002; 9(1): 29-32.

Pedrassani D, Camargo FR. Dioctofimose em cães: primeiro relato da ocorrência de casos no Distrito São Cristóvão, Três Barras - SC. Rev Bras Parasitol Vet 2004; 13(s1): 278.

Pedrassani D, Hoppe EGL, Avancini N, Nascimento AA. Morphology of eggs of Dioctophyme renale Goeze, 1782 (Nematoda: Dioctophymatidae) and influences of temperature on development of first-stage larvae in the eggs. Rev Bras Parasitol Vet 2009a; 18(1): 15-19. PMid:19500455. http:// dx.doi.org/10.4322/rbpv.01801003.
Pedrassani D, Hoppe EGL, Tebaldi JH, Nascimento AA. Chaunus ictericus (Spix, 1824) as paratenic host of the giant kidney worm Dioctophyme renale (Goeze, 1782) (Nematoda: Enoplida) in São Cristóvão district, Três Barras county, Santa Catarina state, Brazil. Vet Parasitol 2009b; 165(1-2): 74-77. PMid:19664882. http://dx.doi.org/10.1016/j.vetpar.2009.07.017.

Pedrassani D, Nascimento AA, André MR, Machado RZ. Improvement of an enzyme immunosorbent assay for detecting antibodies against Dioctophyma renale. Vet Parasitol2015; 212(3-4): 435-438. PMid:26299933. http://dx.doi.org/10.1016/j.vetpar.2015.08.007.

Pedrozo R, Bazán A, Cuevas D, Godoy Y. Valores séricos de urea, creatinina y densidad urinaria en perros com Dioctophyma renale en la ciudad de Caazapá, Paraguay, y su relación con factores de riesgo. Compend Cienc Vet 2013; 03(2): 33-38.

Pereira BJ, Girardelli GL, Trivilin LO, Lima VR, Nunes LC, Martins IVF. Ocorrência de Dioctofimose em cães necropsiados do município de Cachoeiro do Itapemirim, Espírito Santo, Brasil, no período de maio a setembro de 2004. Rev Bras Parasitol Vet 2006; 15(3): 123-125. PMid:16978477.

Rappeti JCS, Tognoli GK, Martins DB, Santarosa IM, Festugatto R, Pippi NL, et al. Dioctofimose assintomática em um cão: relato de caso. MEDVEP: Rev Cient Med Vet 2008; 6(17): 53-57.

Reichmann MLAB, Pinto HBF, Nunes VFP. Vacinação contra a raiva de cães e gatos: manual 3. São Paulo: Instituto Pasteur; 1999.

Rivero JC, Inoue Y, Murakami N, Horii Y. Androgen- and estrogen-dependent sex differences in host resistance to Strongyloides venezuelensis infection in Wistar rats. J Vet Med Sci 2002; 64(6): 457-461. PMid:12130827. http://dx.doi.org/10.1292/jvms.64.457.

Silveira CS, Diefenbach A, Mistieri ML, Machado IRL, Anjos BL. Dioctophyma renale em 28 cães: aspectos clinicopatológicos e ultrassonográficos. Pesq Vet Bras 2015; 35(11): 899-905. http://dx.doi.org/10.1590/S0100736X2015001100005.

Sloss MW, Zajac AM, Kemp RL. Parasitologia clinica veterinária. São Paulo: Manole; 1999.

Tokiwa T, Ueda W, Takatsuka S, Okawa K, Onodera M, Ohta N, et al. The first genetically confirmed case of Dioctophyme renale (Nematoda: Dioctophymatida) in a patient with a subcutaneous nodule. Parasitol Int 2014; 63(1): 143-147. PMid:24095916. http://dx.doi.org/10.1016/j. parint.2013.09.015.

Thrusfield M. Epidemiologia veterinária. 2nd ed. São Paulo: Roca; 2004.

Urano Z, Hasegawa H, Katsumata T, Toriyama K, Aoki Y. Dioctophymatid nematode larva found from human skin with creeping eruption.J Parasitol 2001; 87(2): 462-465. PMid:11318590. http://dx.doi.org/10.1645/00223395(2001)087[0462:DNLFFH]2.0.CO;2.

World Health Organization - WHO. Guidelines for dog population management. Geneva: WHO, 1990.

Zakarian B, Shafaii-Tonkaboni J. Dioctophymosis in Iran. Br Vet J 1972; 128(9): 446-451. PMid:4262897. 